\title{
Pencapaian tekanan intraokular pasca pemberian timolol maleat $0,5 \%$ pada glaukoma sudut terbuka primer di Poliklinik Mata RSUP Prof. Dr. R. D. Kandou Manado tahun 2012 - 2014
}

\author{
${ }^{1}$ Andrea Lalita \\ ${ }^{2}$ Yamin Tongku \\ ${ }^{2}$ J. S. M. Saerang \\ ${ }^{1}$ Kandidat Skripsi Fakultas Kedokteran Universitas Sam Ratulangi Manado \\ ${ }^{2}$ Bagian Ilmu Kesehatan Mata Fakultas Kedokteran Universitas Sam Ratulangi Manado \\ RSUP Prof. Dr. R. D. Kandou Manado \\ Email: andrealalita12121@gmail.com
}

\begin{abstract}
Primary Open Angle Glaucoma (POAG) is the most often type of glaucoma. Glaucoma is one of the most common cause of irreversible blindness worldwide, whereas POAG has nearly $90 \%$ of all types of glaucoma. Timolol maleate $0.5 \%$ is a non-selective beta adrenergic receptor inhibitor commonly used in the POAG treatment. Mechanism of action of this drug is lowering or suppressing the aquous humor production. The level of intraocular pressure (IOP) reduction in patients with timolol can reach a percentage of $20-30 \%$. This was a retrospective descriptive study. Respondents were POAG patients with timolol maleate 0.5\% therapy in the Department of Ophtalmology Prof. Dr. R. D. Kandou Hospital Manado. This study was conducted in November 2015. The results showed that there were 15 respondents who fulfilled the criterias. Of the 15 patients, 8 patients (54\%) came for the first control (a week/a month). There were 9 female patients (60\%) and 6 male patients (40\%). By group of age, the highest percentage was elderly aged 51-60 years (40\%). There were 11 patients (74\%) with bilateral POAG and only 4 patients (26\%) with unilateral POAG. The average percentage of IOP reduction among POAG patients with timolol maleate $0.5 \%$ therapy was $16.52 \%$. Conclusion: Among POAG patients with timolol maleate $0.5 \%$ therapy there was a $16.52 \%$ decrease of the average intraocular pressure in the first control.

Keywords: primary open-angle glaucoma, timolol, intraocular pressure
\end{abstract}

\begin{abstract}
Abstrak: Glaukoma Sudut Terbuka Primer (GSTaP) adalah tipe yang paling sering timbul dari penyakit glaukoma. Glaukoma merupakan salah satu penyebab tersering dari kebutaan yang ireversibel di seluruh dunia, dan GSTaP terdapat hampir 90\% dari semua tipe penyakit glaukoma. Timolol maleat $0,5 \%$ yaitu penghambat reseptor beta adrenergik non selektif merupakan salah satu obat yang paling sering digunakan untuk pengobatan GSTaP. Mekanisme kerja obat ini ialah menurunkan atau supresi produksi humor akuous. Tingkat penurunan TIO (tekanan intraokular) pada pengguna timolol mencapai $20-30 \%$. Penelitian ini bersifat deskriptif retrospektif. Sampel penelitian ialah pasien GSTaP dengan terapi timolol maleat 0,5\% di Poliklinik Mata RSUP Prof. Dr. R. D. Kandou Manado. Penelitian ini dilakukan selama bulan November 2015 dengan jumlah sampel 15 orang yang telah memenuhi kriteria penelitian. Hasil penelitian menunjukkan dari 15 pasien tersebut, 8 pasien (54\%) datang kembali untuk kontrol (1 minggu/1 bulan pertama). Yang berjenis kelamin perempuan lebih banyak yaitu 9 pasien (60\%) sedangkan laki-laki hanya 6 pasien (40\%). Berdasarkan kelompok umur, rata-rata umur lansia paling banyak; yang terbanyak yaitu umur 51-60 tahun (40\%). Dilihat dari sisi mata, kasus bilateral lebih banyak berjumlah 11 pasien (74\%) dibandingkan unilateral hanya 4 pasien (26\%). Rerata persentase penurunan TIO pada pasien GSTaP dengan menggunakan terapi timolol maleat $0,5 \%$ ialah $16,52 \%$. Simpulan: Pada pasien GSTaP yang diberikan timolol maleat $0,5 \%$ terdapat rerata penurunan TIO sebesar $16,52 \%$ pada kontrol pertama.
\end{abstract}

Kata kunci: glaukoma sudut terbuka primer, timolol, tekanan intraokular 
Glaukoma adalah salah satu penyebab tersering dari kebutaan yang tidak dapat diperbaiki di seluruh dunia. Telah diperkirakan bahwa hampir 70 juta orang diseluruh dunia menderita penyakit ini. The World Health Organization (WHO) melaporkan 5.1 juta orang telah mengalami kebutaan karena glaukoma. ${ }^{1-2}$ Jumlah penyakit glaukoma di dunia oleh WHO diperkirakan $\pm 60,7$ juta orang di tahun 2010, dan akan menjadi 79,4 juta di tahun $2020 .^{3}$

Glaukoma Sudut Terbuka Primer (GSTaP) merupakan tipe yang paling sering timbul dari penyakit ini, dimana terdapat pada hampir $90 \%$ dari semua tipe penyakit glaukoma. ${ }^{1}$ WHO memperkirakan bahwa jumlah populasi dunia dengan Tekanan Intraokular (TIO) yang tinggi 104.5 juta orang. Insiden GSTaP diperkirakan akan mencapai 2.4 juta orang per tahun. ${ }^{4}$

Di Amerika Serikat, glaukoma menjadi penyebab kebutaan kedua dan penyebab kebutaan paling sering diantara orang AfroAmerika. ${ }^{2}$ Perkiraan prevalensi GSTaP di Amerika Serikat pada individu yang berusia lebih dari 40 tahun ialah 1,86\%. ${ }^{4}$

Hasil survei Departemen Kesehatan Republik Indonesia tahun 1982 didapatkan prevalensi kebutaan karena glaukoma 0,10\% dan terjadi peningkatan dua kali lipat pada survei $1996 .^{5}$

Pada tahun 2007, Badan Penelitian dan Pengembangan Kesehatan Indonesia membuat Laporan Nasional Hasil Riset Kesehatan Dasar dan mendapatkan prevalensi glaukoma di Indonesia sudah mencapai 4,6\%. Dari hasil riset yang sama, Provinsi Sulawesi Utara dinyatakan mencapai prevalensi glaukoma sebesar $4,7 \%{ }^{6}$

Dari 33 pasien (66 mata) yang datang ke Poliklinik Mata RSU Prof. Dr. R. D. Kandou Manado dengan kelainan glaukoma pada bulan Januari-Desember 2011 didapatkan 57 kasus (86,3\%) kelainan GSTaP. ${ }^{7}$

Timolol maleat $0,5 \%$ adalah penghambat reseptor beta adrenergik non selektif yang digunakan untuk pengobatan
GSTaP dan merupakan salah satu obat yang paling sering digunakan. Mekanisme kerja obat ini ialah menurunkan atau supresi produksi humor akuous. ${ }^{8}$ Menurut American Academy of Ophtalmology, tingkat penurunan TIO pada pasien dengan timolol maleat mencapai $20-30 \%{ }^{4}$

Pada glaukoma akan terdapat karakteristik seperti melemahnya fungsi mata dengan terjadinya cacat/pengecilan lapang pandang, peningkatan TIO yang disertai oleh pencekungan diskus optikus dan kerusakan anatomi berupa ekskavasi (penggaungan) serta degenerasi papil saraf optik, yang dapat berakhir dengan kebutaan. ${ }^{9,10}$ Pada umumnya indikator yang digunakan untuk menilai perkembangan glaukoma adalah pemeriksaan TIO, tajam penglihatan dan perimetri. ${ }^{11}$

Kebutaan pada penderita glaukoma terjadi akibat kerusakan saraf optik yang terjadi melalui mekanisme mekanis akibat TIO yang tinggi dan/atau adanya iskemia sel akson saraf akibat TIO maupun insufisiensi vaskular yang selanjutnya mempengaruhi progresifitas penyakit. ${ }^{12}$

GSTaP tidak menunjukkan gejala sampai kehilangan lapang pandang yang signifikan telah terjadi. Ini terjadi karena kerusakan terjadi secara bertahap dan fiksasi terlibat di akhir perjalanan penyakit. Tanda-tanda yang terjadi pada GSTaP ialah sebagai berikut: 1) TIO meningkat; 2) Fluktuasi diurnal pada TIO terjadi hingga 5 mmHg pada sekitar 30\% dari TIO normal; 3) Perubahan diskus optikus; 4) Lapang Pandang menunjukan perubahan yang tipikal; 5) Gonioskopi menunjukan sudut terbuka yang normal. ${ }^{13}$

Ada dua teori mekanisme kerusakan saraf optik yang diakibatkan TIO meliputi kerusakan mekanik pada akson saraf optik dan penurunan aliran darah pada papil saraf optik sehingga terjadi iskemia akson saraf. Pencegahan atau pengendalian faktor resiko, terutama peningkatan TIO ialah tujuan utama manajemen glaukoma. ${ }^{14}$

Tanpa pengobatan, GSTaP dapat berkembang secara perlahan sehingga akhirnya menimbulkan kebutaan total. Apabila proses penyakit terdeteksi secara 
dini, sebagian besar pasien glaukoma dapat ditangani dengan baik secara medis. ${ }^{10}$

Pengobatan untuk menurunkan TIO telah terbukti secara signifikan memperlambat atau mungkin menghentikan perkembangan penyakit. Banyak uji klinis telah mengonfirmasi kemanjuran penurunan TIO. ${ }^{4}$

Timolol maleat merupakan beta bloker adrenoseptor yang banyak digunakan dalam pengobatan glaukoma, khususnya dalam pengobatan GSTaP, dan merupakan obat pembanding pada penelitian klinis terhadap obat antiglaukoma baru. ${ }^{14,15}$

\section{METODE PENELITIAN}

Penelitian ini menggunakan metode deskriptif restrospektif. Data diambil dari rekam medis di Poliklinik Mata RSUP Prof. Dr. R.D. Kandou Manado Populasi penelitian ialah seluruh data rekam medis penderita GSTaP dengan pemberian timolol maleat $0,5 \%$ di Poliklinik Mata RSUP Prof. Dr. R. D. Kandou Manado periode Januari 2012 - Desember 2014. Kriteria penelitian ialah pasien terdiagnosis GSTaP dan diberikan timolol maleat 0,5\%, datang mengontrol TIO pertama kali 1 minggu dan atau 1 bulan kemudian setelah terapi timolol maleat $0,5 \%$.

\section{HASIL PENELITIAN}

Tabel 1 memperlihatkan distribusi frekuensi pasien dari data rekam medik periode Januari 2012 - Desember 2014. Terdapat 6 orang (40\%) pasien berjenis kelamin laki-laki dan 9 orang (60\%) perempuan.

Tabel 1. Distribusi frekuensi pasien GSTaP berdasarkan jenis kelamin

\begin{tabular}{ccc}
\hline Jenis kelamin & $\mathrm{N}$ & $\%$ \\
\hline Laki-laki & 6 & 40 \\
Perempuan & 9 & 60 \\
Jumlah & 15 & 100 \\
\hline
\end{tabular}

Tabel 2 memperlihatkan distribusi GSTaP berdasarkan umur dan diperoleh hasil terbanyak yaitu 6 pasien (40\%) pada kelompok usia 51-60 tahun.
Tabel 2. Distribusi frekuensi Pasien GSTaP berdasarkan umur

\begin{tabular}{lcc}
\hline Umur & $\mathrm{N}$ & $\%$ \\
\hline $11-20$ & 1 & 6,7 \\
$21-30$ & 1 & 6,7 \\
$31-40$ & 0 & 0 \\
$41-50$ & 1 & 6,7 \\
$51-60$ & 6 & 40 \\
$61-70$ & 3 & 20 \\
$>70$ & 3 & 20 \\
Jumlah & 15 & 100 \\
\hline
\end{tabular}

Tabel 3 memperlihatkan distribusi frekuensi pasien GSTaP unilateral/bilateral. Terdapat sebanyak 4 pasien (26\%) GSTaP unilateral dan 11 pasien (74\%) GSTaP bilateral.

Tabel 3. Distribusi frekuensi Pasien GSTaP unilateral/bilateral

\begin{tabular}{ccc}
\hline Sisi Mata & Frekuensi & $\%$ \\
\hline Unilateral & 4 & 26 \\
Bilateral & 11 & 74 \\
Jumlah & 15 & 100 \\
\hline
\end{tabular}

Tabel 4 memperlihatkan distribusi frekuensi pasien GSTaP yang kontrol setelah terapi. Pasien yang datang untuk kontrol 1 minggu dan atau 1 bulan setelah terapi sebanyak 8 orang (54\%), sedangkan pasien yang tidak datang kontrol 1 minggu dan atau 1 bulan setelah terapi sebanyak 7 orang (46\%).

Tabel 4. Distribusi frekuensi Pasien GSTaP yang kontrol setelah terapi

\begin{tabular}{ccc}
\hline Pasien GSTaP & $\mathrm{N}$ & $\%$ \\
\hline Kontrol setelah 1 & 8 & 54 \\
minggu dan atau 1 bulan \\
$\begin{array}{c}\text { Tidak datang kontrol } \\
\text { setelah } 1 \text { minggu dan } \\
\text { atau } 1 \text { bulan } \\
\text { Jumlah }\end{array}$ & 7 & 46 \\
\hline
\end{tabular}

Berdasarkan Tabel 5 dapat dilihat bahwa dari 8 pasien yang datang untuk kontrol setelah terapi, sebagian besar pasien menunjukkan penurunan yang nyata kecuali pasien ke-3 dan pasien ke-7. Pasien 
ke-3 menunjukkan TIO sebesar OD 17 $\mathrm{mmHg}$ dan OS $23 \mathrm{mmHg}$, setelah terapi menjadi OD $17 \mathrm{mmHg}$ dan OS $24 \mathrm{mmHg}$ dimana tidak menunjukkan penurunan TIO.
Pasien ke-7 menunjukkan TIO sebesar OD $14 \mathrm{mmHg}$ dan OS $22 \mathrm{mmHg}$, dan yang mengalami penurunan hanya OS sebesar 18 mmHg (18\%).

Tabel 5. Persentase penurunan TIO pada pasien GSTaP setelah terapi Timolol Maleat $0,5 \%$ dan datang kontrol setelah 1 minggu dan atau 1 bulan.

\begin{tabular}{cccccccc}
\hline \multirow{2}{*}{$\begin{array}{c}\text { Pasien } \\
\text { ke- }\end{array}$} & $\begin{array}{c}\text { Usia pasien } \\
\text { GSTaP }\end{array}$ & \multicolumn{2}{c}{$\begin{array}{c}\text { TIO Sebelum } \\
\text { Terapi }\end{array}$} & \multicolumn{2}{c}{$\begin{array}{c}\text { TIO Setelah } \\
\text { Terapi }\end{array}$} & \multicolumn{2}{c}{ Penurunan TIO } \\
\cline { 3 - 8 } & & OD & OS & OD & OS & OD & OS \\
1 & 60 tahun (1) & 17,3 & 17,3 & 14,6 & 14,6 & 16 & 16 \\
2 & 65 tahun & 13 & 22,7 & 11 & 18 & 15 & 21 \\
3 & 80 tahun & 17 & 23 & 17 & 24 & 0 & - \\
4 & 73 tahun & 14,6 & 14,6 & 14 & 5 & 4 & 61 \\
5 & 55 tahun (1) & 14,6 & 17,3 & 10 & 12 & 31 & 30 \\
6 & 60 tahun (2) & 21 & 21,9 & 17,3 & 17,3 & 18 & 21 \\
7 & 55 tahun (2) & 14 & 22 & 19 & 18 & - & 18 \\
8 & 58 tahun & 18 & 13,7 & 12,3 & 11,3 & 32 & 17 \\
\hline
\end{tabular}

Gambar 1 memperlihatkan bahwa rerata TIO sebelum terapi dengan menggunakan timolol maleat $0,5 \%$ ialah $17,625 \mathrm{mmHg}$, sedangkan rata-rata TIO sesudah terapi saat pertama kali kontrol 14,7125 mmHg. Persentase penurunan TIO pada pasien GSTaP dengan menggunakan terapi timolol maleat $0,5 \%$ ialah $16,52 \%$.

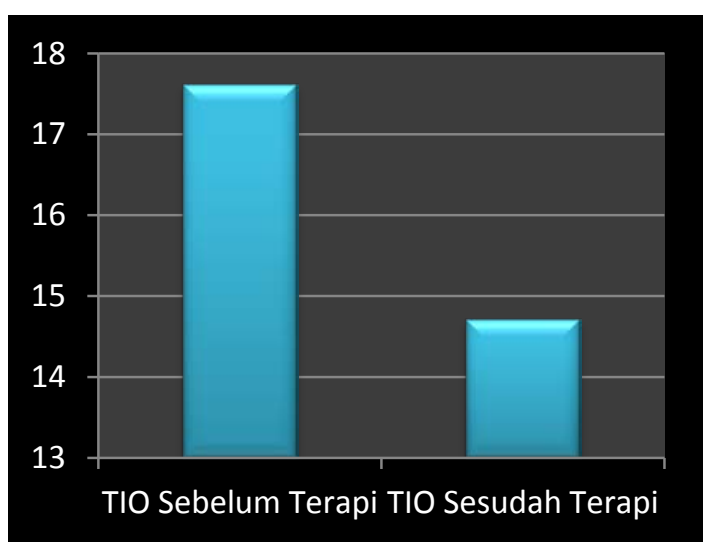

Gambar 1. Penurunan TIO pada pasien GSTaP dengan terapi Timolol Maleat 0,5\% setelah kontrol pertama kali

\section{BAHASAN}

Berdasarkan hasil penelitian deskriptif retrospektif tentang kasus GSTaP di
Poliklinik Mata RSUP Prof. Dr. R. D. Kandou Manado periode Januari 2012 Desember 2014, dari data rekam medik pasien dengan pemberian Timolol Maleat 0,5\% didapatkan 15 pasien GSTaP. Pada Tabel 1 dipaparkan bahwa jenis kelamin perempuan (60\%) lebih banyak dibandingkan laki-laki (40\%).

Beberapa penelitian menemukan adanya perbedaan dalam prevalensi GSTaP berdasarkan perbedaan jenis kelamin. Contohnya, Australian Blue Mountain Study menemukan prevalensi GSTaP lebih besar pada wanita, sedangkan Barbados Study dan Rotterdam Study menemukan prevalensi GSTaP lebih tinggi pada lakilaki. ${ }^{1}$ Juga pada penelitian yang dilakukan di India, prevalensi GSTaP pada perempuan lebih tinggi daripada laki-laki, ${ }^{16}$ sedangkan pada beberapa penelitian yang lain belum ditemukan perbedaan yang signifikan dalam insiden dan prevalensi GSTaP antara kedua jenis kelamin. ${ }^{1}$ Pada penelitian ini, ditemukan prevalensi GSTaP pada perempuan lebih tinggi daripada lakilaki.

Berdasarkan umur pada Tabel 2, prevalensi GSTaP memliki jumlah terendah pada umur $<50$ tahun, sedangkan jumlah 
tertinggi pada umur $>50$ tahun. Risiko untuk GSTaP meningkat dengan bertambahnya usia. Secara klinis, sebagian besar praktisi mulai mempertimbangkan usia sebagai faktor resiko GSTaP pada usia 40. ${ }^{1}$ Terdapat bukti kuat bahwa usia yang lebih tua merupakan faktor risiko independen dalam berkembangnya penyakit glaukoma. Hal ini telah dikonfirmasi oleh beberapa uji klinis longitudinal serta oleh beberapa penelitian berbasis populasi, ${ }^{8}$ seperti pada penelitian yang dilakukan oleh Yadav et al, ${ }^{16}$ prevalensi GSTaP ditemukan paling tinggi pada rentang kelompok usia 40-60 tahun. Juga penelitian yang dilakukan oleh Framingham Study dan Ferndale Glaucoma Study menunjukkan prevalensi GSTaP sekitar $0,7 \%$ penduduk yang berusia 52-64 tahun dan meningkat menjadi $1,6 \%$ penduduk pada usia $65-74$ tahun, serta menjadi $4,2 \%$ pada usia $75-85$ tahun. ${ }^{17}$

Tabel 3 menunjukkan perbedaan prevalensi antara pasien GSTaP unilateral dan bilateral. Terdapat perbedaan nyata dimana pasien GSTaP unilateral sebanyak 4 orang (26\%) dan pasien GSTaP bilateral sebanyak 11 orang (74\%). Penelitian yang dilakukan oleh August ${ }^{18}$ pada tahun 2008, menunjukkan hasil yang serupa dengan penelitian ini dimana dari 50 sampel, mayoritas sebanyak 42 pasien (84\%) mengalami GSTaP bilateral, sedangkan hanya sebanyak 8 pasien (16\%) yang mengalami GSTaP unilateral.

Hasil penelitian ini tidak menunjukkan perbedaan yang signifikan berdasarkan prevalensi pasien GSTaP yang datang kembali untuk kontrol pertama kali dalam 1 minggu dan atau 1 bulan setelah terapi (Tabel 4). Walaupun demikian, setiap pasien GSTaP harus dididik untuk memahami bahwa pengobatan GSTaP merupakan suatu proses seumur hidup dan bahwa penilaian ulang secara teratur oleh ahli oftalmologi penting dilakukan. Tanpa pengobatan, GSTaP dapat berkembang secara perlahan sehingga akhirnya menimbulkan kebutaan total. ${ }^{10}$

Pada Tabel 5 dipaparkan persentase penurunan TIO pada pasien GSTaP setelah terapi timolol maleat $0,5 \%$ dan datang kontrol setelah 1 minggu dan atau 1 bulan. Menurut hasil penelitian, terdapat pasien yang mengalami penurunan maupun yang tidak mengalami penurunan setelah diberikan terapi timolol maleat $0,5 \%$. Hal tersebut disebabkan oleh adanya faktor risiko lain yang harus dipertimbangkan dalam pemberian terapi timolol maleat $0,5 \%$, yaitu: usia $>60$ tahun, kecenderungan genetik, karakteristik mata tertentu (seperti cacat pupil, kornea tipis, miopia), status pendidikan yang rendah, merokok, dan masalah pemglihatan (seperti mata hipertensi, rasio cup disk horizontal atau vertikal yang lebih besar, penyimpangan pola bidang visual lebih besar, bidang visual asimetri, dan IOP). ${ }^{19}$

Pada Gambar 1 dipaparkan hasil penelitian penurunan TIO pada pasien GSTaP dengan pemberian terapi timolol maleat $0,5 \%$ sebesar $16,52 \%$. Hasil ini lebih kecil dari peneltian-penelitian yang telah dilaporkan dimana diharapkan penurunan TIO yang terjadi sebesar 20$30 \%{ }^{4}$

Menurut hasil penelitian yang dilakukan oleh Joon et al, ${ }^{20}$ timolol maleat $0,5 \%$ berhasil menurunkan TIO mencapai 23,53\%. Serupa dengan penelitian yang dilakukan oleh Valk et al. ${ }^{21}$ dimana persentase penurunan timolol maleat $0,5 \%$ mencapai 27,2\%. Namun, berbeda dengan hasil penelitian yang dilakukan oleh August ${ }^{18}$ dengan monoterapi timolol maleat $0,5 \%$ hanya mencapai persentase penurunan TIO sebesar 15,93\%.

Terapi untuk GSTaP bertujuan untuk meningkatkan drainase humor akuous yang berlebihan, melalui outflow uveoscleral dan pada jaringan trabekular. Dengan kata lain, terapi ini tidak memadai menargetkan jaringan trabekular, yang menyajikan permukaan paling luas untuk drainase. Untuk alasan ini bahwa tidak ada satu terapi yang mampu mengurangi TIO dengan lebih dari 25\%. Akibatnya, pasien harus diberikan lebih dari satu terapi untuk mengontrol GSTaP dan kepatuhan menjadi masalah. $^{19}$

Monoterapi bukan merupakan jawaban 
dan terapi lain harus ditambahkan atau pendekatan lainnya dipertimbangkan. Dengan pemberian resep terapi kombinasi, ahli oftalmologi mencapai pengurangan TIO yang lebih tinggi dengan semua kemungkinan mekanisme yang tidak diperoleh dengan pemberian monoterapi. $^{16,19}$ Penelitian yang dilakukan oleh August $^{18}$ menemukan hasil dari terapi kombinasi timolol maleat $0,5 \%$ dan asetazolamid menurunkan TIO lebih besar dibandingkan timolol maleat $0,5 \%$ dipakai hanya sebagai monoterapi. Demikian juga dengan penelitian oleh Pacella et al. ${ }^{22}$ yang dilakukan di Roma, Itali pada tahun 2010, menunjukkan bahwa penggunaan terapi kombinasi timolol maleat $0,5 \%$ dan latanoprost $\quad 0,0005 \%$ sekali sehari mengurangi TIO lebih tinggi dibandingkan dengan penggunaan dua kali sehari monoterapi Timolol Maleat 0,5\%.

Pada penelitian prospektif yang dilakukan di India pada tahun 2013, beta bloker ditemukan menjadi obat yang paling sering diresepkan untuk penderita GSTaP dengan timolol menjadi obat yang paling sering diresepkan sebagai monoterapi. Beta bloker ditemukan menjadi yang termurah dari semua obat anti-glaukoma dengan harga termurah untuk timolol dan betaxolol. ${ }^{16}$ Demikian juga di Poliklinik Mata RSUP Prof Dr. R. D. Kandou Manado, beta bloker khususnya timolol maleat $0,5 \%$ ditemukan menjadi obat yang paling sering diresepkan untuk penderita GSTaP sebagai monoterapi ataupun sebagai terapi kombinasi.

Limitasi penelitian ini ialah penelitian ini menggunakan metode retrospektif dengan data rekam medik yang kurang lengkap, banyak data penting tidak tercantum dengan baik atau penulisannya kurang jelas atau hilang. Selain itu sedikitnya jumlah pasien GSTaP yang datang ke Poliklinik Mata RSUP Prof Dr. R. D. Kandou Manado pada tahun 20122014.

\section{SIMPULAN}

Dari hasil penelitian deskriptif restrospektif tentang pasien GSTaP di
Poliklinik Mata RSUP Prof. Dr. R. D. Kandou Manado periode Januari 2012 Desember 2014 dapat disimpulkan terdapat rerata pencapaian TIO pasca pemberian timolol maleat $0,5 \%$ sebesar $16,52 \%$.

\section{SARAN}

1. Perlu adanya pencatatan rekam medik yang lebih lengkap dan lebih jelas mengenai terapi pada suatu penyakit mata.

2. Perlu adanya penelitian lebih lanjut dan follow-up lebih lama (lebih dari 1 bulan) mengenai terapi timolol maleat $0,5 \%$ sebagai terapi inisial pada pasien GSTaP ke depannya.

\section{DAFTAR PUSTAKA}

1. Gupta D. Glaucoma: Diagnosis and management. Philadelpia: Lippincot Williams \& Wilkins, 2005.

2. Allingham R, Damji K, Freedman S, Moroi S, Shafranov G. Shields' Textbook of glaucoma (6th ed). Philadelpia: Lippincot Williams \& Wilkins, 2011; p. 1.

3. Artini W, Dame. Glaucoma caused blindness with its characteristic in cipto mangunkusumo hospital. Jurnal oftalmologi indonesia. 2011;7:18993.

4. American Academy of Ophtalmology. Glaucoma: basic and clinical science course, Section 10. San Fransisco: The Foundation of the American Academy of Ophtalmology 20152016.

5. Departemen Kesehatan RI. Hasil survei kesehatan indera penglihatan dan pendengaran. Jakarta: Dirjen pembinaan kesehatan masyarakat direktorat bina upaya kesehatan puskesmas, 1998.

6. Badan Penelitian dan Pengembangan Kesehatan. Riset Kesehatan Dasar (Riskesdas 2007). Jakarta: Kementerian Kesehatan Republik Indonesia, 2007.

7. Indriani R, Satolom N. Pengobatan terkini pada glaukoma sudut terbuka primer. Tinjauan Kepustakaan. Program Pendidikan Dokter Spesialis I Bagian/SMF Ilmu Penyakit Mata Fakultas Kedokteran Universitas Sam 
Ratulangi; 2015.

8. Weinreb R, Araie $M$, Susanna $R$, Goldberg I, Migdal C, Liebmann J. Medical treatment of glaucoma. Amsterdam: Kugler Publications, 2010; p. 37-41.

9. Sidarta I. Ilmu penyakit mata (3rd ed). Jakarta: Balai Penerbit FKUI, 2004; p. 212.

10. Vaughan D, Asbury T, Riordan-Eva $P$. Oftalmologi umum (17th ed). Jakarta: Widya Medika, 2010; p. 220-39.

11. Rosalina D, Wahjudi $H$. Visual field abnormality and quality of life of patient with primary open angle glaucoma. Jurnal Oftalmologi Indonesia. 2011;7:175-80.

12. Ismandari F, Helda. Kebutaan pada pasien glaukoma primer di rumah sakit umum Dr. Cipto Mangunkusumo Jakarta. Jurnal Kesehatan Masyarakat nasional. 2011;5:185-92.

13. Kanski J. Clinical ophtalmology a systematic approach (7th ed). Edinburgh: Butterworth Heinemann, 2011. p. 193-4

14. Virgana R. Ocular Pharmacoterapy in Glaukoma. Bandung: Bagian Ilmu Kesehatan Mata Fakultas Kedokteran Universitas Padjajaran, 2007.

15. Ghelani T, Seth A, Saini V, Singhal S, Kumar S, Yadav Y. Formulation and evaluation of timolol maleat ocular insert. Asian Journal of Biochemical and Pharmaceutical Research. 2011;1:166-74.

16. Yadav A, Patel V. Drug use in primary open angle glaucoma: A prospective study at a tertiary care teaching hospital. Indian Journal of Pharmacology. 2013;45:117-20.
17. Soeroso A. The role of Il-10 cytokine in increased intraocular pressure on Primary Open Angle Glaucoma. Jurnal Oftalmologi Indonesia. 2007;5:124-37.

18. August J. Perbandingan Efek Timolol dengan Kombinasi Timolol + Asetazolamid pada Terapi Inisial Glaukoma Primer Sudut Terbuka [Karya Tulis Ilmiah]. Semarang: Universitas Diponegoro; 2008.

19. Beidoe G, Mousa S. Current primary openangle glaucoma treatments and future directions. Clinical Ophtalmology. 2012;6:1699-707.

20. Joon Mo K, Tae-Woo K, Chan-Yun K, Hwang-Ki K, Kim Ho P. Comparison of the intraocular pressure-lowering and safety of brimonidine/timolol fixed combination and 0,5\% timolol in normaltension glaucoma patients. Japanese Journal of Ophtalmology. 2015.

21. Valk R, Webers C, Hendrikse F, Vogel S, Prins M, Schouten J. Predicting intraocular pressure change before initiating therapy: timolol versus latanoprost. Acta Ophtamologica. 2008;86:415-18.

22. Pacella E, Pacella F, Cavallotti C, Librando A, Feher J, PecoriGiraldi J. The combination latanoprost-timolol versus twice daily $0.50 \%$ timolol administration either associated or not with latanoprost: efficacy and tolerability in the Primary Open-Angle Glaucoma. European Review for Medical and Pharmacological Sciences. 2010;14: 477-80. 